A. N. Galushchinsky, K. L. Obydennov

LTD «Y-Synthesis», Lunacharskogo st., Ekaterinburg, 620027, Russia E-mail:k.l.obydennov@urfu.ru

\title{
The production of novolac oligomers
}

The paper presents the improvement of production technology of novolac phenol-formaldehyde oligo-mers by introducing the new scheme of capture of exhaust gases due to waste production, which leads to a reduction of costs and increase economic efficiency. The calculation of the material balance of the pro-duction of novolac phenol-formaldehyde oligomer at $300 \mathrm{~kg} / \mathrm{h}$ of technical product is performed, the technological calculation of the basic equipment and selection of auxiliary equipment is produced. The apparatus scheme of production is made and the description of the process is represented. The draft of the main reactor is made.

Key words: phenol; formalin; oxalic acid; novolac; oligomer; the polycondensation reaction; material cal-culations; production technology; instrumental scheme.

Received: 24.09.2016; accepted: 14.10.2016; published: 30.12.2016.

\section{Производство новолачных олигомеров}

\author{
А. Н. Галущинский, К. Л. Обыденнов \\ ООО «У-Синтез», ул. Луначарского, 60, \\ 620027, Екатеринбург, Россия \\ E-mail:k.l.obydennov@urfu.ru
}

В работе представлено усовершенствование технологии производства новолачных фено-лоформальдегидных олигомеров путем введения новой схемы улавливания отходящих газов за счет отходов производства, что приводит к сокращению расходов и увеличению экономической эффективности. Выполнен расчет материального баланса производства новолачного фенолоформальдегидного олигомера на 300 кг/ч технического продукта, произведен технологический расчет основного и выбор вспомогательного оборудования. Составлена аппаратурная схема производства, а также представлено описание технологического процесса. Выполнен чертеж основного реактора.

Ключевые слова: фенол; формалин; щавелевая кислота; новолак; олигомер; реакция поли-конденсации; материальные расчеты; технология производства; аппаратурная схема.

Поступило: 24.09.2016; принято: 14.10.2016; опубликовано: 30.12.2016.

(c) Galushchinsky A. N., Obydennov K. L., 2016

\section{Introduction}

Phenol-formaldehyde oligomers is the first plastic mass obtained by the reaction of polycondensation. They are prepared from phenols and aldehydes, primarily formaldehyde. Cresols, xylenols, polyatomic phenols, alkylphenols, 
polynuclear compounds, such as bisphenol etc., are used as phenolic raw material along with the use of phenol. Depending on the ratio of reactants and catalysis method either novolacs (excess of phenols with catalysis by acids) or resoles (excess of formaldehyde with catalysis by bases) are made.

In the period of rapid development of the plastics it's hard to give a prediction about the future of phenol-formaldehyde oligomers - the oldest of polymeric materials; it is safe to say that at the present time they not only lost their value, but there is reason to expect long-term, although the slight absolute increase in the production of phenolic plastics despite the decrease in their relative part in the total output of plastics.

Phenol-formaldehyde oligomers were the first synthetic industrial thermosetting plastics. The deficit of natural raw materials and the need to replace natural materials with synthetic served as the impetus for their production.

Noteworthy is the fact that the socalled classical phenol-formaldehyde thermosetting plastics and thermoplastics despite the decline in their relative part in the world production of plastics not only lost their positions, but on the contrary have assumed much greater importance. In this regard and with the much tougher ecological standards, the search for the most economical and ecological technology for the production of phenol-formaldehyde oligomers, in particular novolacs, requires what this work is devoted.

Brief characteristics and main fields of applications of phenol-formaldehyde novolac oligomers

The color of the non-cured oligomers is from light-yellow to dark brown; the average molecular weight is $400-1000 \mathrm{~g} / \mathrm{mol}$, the melt density is $1.14-1.22 \mathrm{~g} / \mathrm{cm}^{3}$, viscosity is $00-200$ Pa.s. The density of the solid resins is 1.22 to $1.27 \mathrm{~g} / \mathrm{cm}^{3}$, Ubbelode dropping point is $70-130{ }^{\circ} \mathrm{C}$. The unhardened oligomers are soluble in phenols and alkaline solutions, in organic solvents [1].

The unhardened oligomers exposed to partial swelling under prolonged contact with water, they are practically insoluble in organic solvents, although the contained in them oligomers can be partially recovered by extraction. Resites slowly dissolve with decomposition under the influence of aqueous alkali or phenol melts. They are resistant to most acids, except concentrated sulphuric and acidoxidants.

At full or partial replacement of phenol to cresol or xylenol oligomers when cured have improved dielectric properties.

The properties of filled oligomers are caused to a large extent by the filler.

The unhardened oligomers are stable for a long time when heated up to $200{ }^{\circ} \mathrm{C}$ and partially are able to resist the action of higher temperatures (days at $200-250{ }^{\circ} \mathrm{C}$, hours at $250-500{ }^{\circ} \mathrm{C}$, minutes at $500-$ $1000{ }^{\circ} \mathrm{C}$, a few seconds at $1000-1500^{\circ} \mathrm{C}$ ). The decomposition of the unhardened resins begins at temperatures around 300 ${ }^{\circ} \mathrm{C}$ and is accompanied by the release of pyrolysis products (homologs of phenol and benzene, carbon dioxide, etc.).

The oxidizers and acids accelerate this process. At higher temperature the charring occurs with the formation of coke. The presence of substituents in the phenolic nuclei reduces the thermal stability of resins: oligomers obtained from phenols quickly begin to decompose already at $230^{\circ} \mathrm{C}$.

Main fields of application of the PFO [2]:

Foams plastics and foam blocks 
They are obtained by the gas filling of resoles with fillers by hydrocarbons (technology is similar to the production of polystyrene), are used as heat- and soundinsulation material having high thermostability and fire resistance compared to geofoam.

\section{Glues and adhesive materials}

The glues based on phenol-formaldehyde resins intended to associate the wood fibers (matrix fiberboard, particleboard, plywood) are widespread. The viscous PFO use for cold welding of light metals and plastic products (for example, seaming of linoleum pieces), the compositions on their basis with modifications are able to work in extreme conditions; their solutions in ethanol or other volatile solvents are used as medical adhesives for wound healing.

\section{Press mass}

The pressed powders are used for casting of finished goods (which are used less in recent years) and for the preparation of composite materials with different fillers; widely used in composition of building mixtures to create coatings or adhesive layers.

\section{Lacquer resins}

Used as replacement of natural shellac, as dielectric coatings and protection of metals from corrosion. "Liquid novolac", a solution of novolak in ethylene glycol, which is used as anti-corrosion coating in shipbuilding, is produced increasingly at the present time.

\section{Laminates}

Composites based on phenol-formaldehyde oligomers are used as a light strong material to facilitate construction as well as materials resistant to adverse conditions and have good dielectric properties. Also they are used for forming tubes and rods of various types.

\section{Ion exchange resins}

Practically all range of cationic, anionic, amphoteric and other resins, containing aromatic monomer of substituted benzene, are widely used in wastewater treatment, water treatment and catalysis in the chemical industry.

\section{Brief characteristic of raw materials} used in the production of phenol-formaldehyde novolac oligomers

Phenol<smiles>Oc1ccccc1</smiles>

Colorless crystalline substance with the specific smell of gouache, MP is $40.9{ }^{\circ} \mathrm{C}$, the boiling temperature is $181.8^{\circ} \mathrm{C}$, the density is about $1030 \mathrm{~kg} / \mathrm{m}^{3}$. Under air oxidation phenol becomes pink. The impurities significantly reduce the melting point of the phenol. The solubility in water is of about $8 \%$; under heating to $84{ }^{\circ} \mathrm{C}$ it mixes with water in any ratio. The aqueous solutions of alkalis easily dissolve the phenol with the formation of phenolates. Phenol is soluble in formalin, ethanol, diethyl ether, glycerol, benzene, turpentine, fatty acids and their esters [2].

The chemical activity of phenol in the synthesis of phenol aldehyde resins is explained by the presence of three active protons in its molecule or two in the ortho- and one in para-position to the hydroxyl group.

\section{Cresols (Methylphenols)}

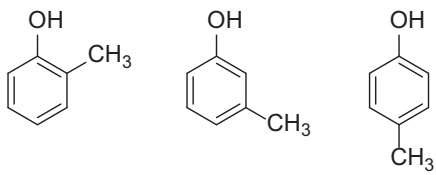

Phenols attach formaldehyde only to the ortho- and para-position to the hydroxyl group, therefore, $m$-cresol with 
three active protons giving thermoreactoplastics are more functionalized; o - and p-cresols, which are only bifunctional, give thermoplastics.

Because of the difficulty of separation of cresols, the mixture of three isomers called tricresol is often uses: the density of liquid is $1044 \mathrm{~kg} / \mathrm{m}^{3}$, boiling point is 185-205 ${ }^{\circ} \mathrm{C}$ depending on the content of isomers and impurities. Tricresol is soluble in ethanol, diethyl ether and alkaline solutions, about $2.5 \%$ of tricresol dissolves in the water. The fraction of coal tar, boiling in the range of $160-250{ }^{\circ} \mathrm{C}$, which is cleaned from a large part of the naphthalene, can be used for tricresol manufacturing.

\section{Xylenols (dimethylphenols)}<smiles>Cc1ccc(O)c(C)c1</smiles>

Xylenol has six isomers. The technical xylenol is the mixture of isomers, it's the viscous oil of a brownish-black color with a strong unpleasant odor, the boiling point is $200-220^{\circ} \mathrm{C}$, the density is $1040 \mathrm{~kg} / \mathrm{m}^{3}$, it's soluble in $10 \%$ aqueous alkali solution. The main source of xylenols is the cresol fractions of resins obtained from the thermal processing of fuels. In view of its bifunctionality, it's not able to form the mesh structure and without the introduction of additional raw materials is suitable only for thermoplastic oligomers manufacturing.

\section{Bisphenol $A$ and its derivatives}<smiles>CC(C)(c1ccc(O)cc1)c1ccc(O)cc1</smiles>

The condensation products of phenols and acetone under catalysis by mineral acids, which have several active centers (up to 4), and as a consequence, are able to link oligomeric chains by adding to the basic raw material to improve their heat resistance and rigidity.

\section{Furfuryl alcohol}<smiles>OCc1ccco1</smiles>

Derivative of furfural, which increases the thermosetting properties and the viscosity of the polymer; has a highly active center in the 5-position of the furan cycle.

\section{Chlorophenols}

Mono-, di- and trisubstituted products of chlorination of phenol. They are less active than phenols and cresols, but more acidity, and at the same time they give the higher combusting resistance to the product due to the presence of chlorine atoms.

\section{The highest phenols}

This group includes hydroxynaphthalenes, phenolic derivatives of anthracene, phenanthrene, etc. By the addition to oligomers they give them high thermal stability (up to $400^{\circ} \mathrm{C}$ ), growing with increasing number of condensed cycles in phenol.

\section{Formalin}

The aqueous $37 \%$ solution of formaldehyde at room temperature or up to $50 \%$ at increased temperature. During reaction with the phenols it enters into electrophilic aromatic substitution, "stitching" between the aromatic nuclei and thereby forming oligomers. The solid derivatives of formaldehyde - paraform and urotropin (methenamine) - are sometimes used as a replacement for the unstable solution in the production. 


\section{Lignin}

Natural oligomer, which is part of the wood. It has phenolic centers, linked by saturated hydrocarbon chains (3-4 atoms). The oligomer obtained using lignin contains less quantity of free phenol and is also biodegradable, that facilitates its disposal and does less harm to the environment. The production of lignin-based oligomers is currently becoming increasingly important in developed countries in connection with stricter of ecological regulations.
Novolac phenolformaldehyde oligomers are obtained, as a rule, by the polycondensation of phenol and formaldehyde (in form of formalin) in an acidic aqueous mass; the various additives to the starting materials have only the limited application. The production is carried out by periodic or continuous scheme [3]. In this paper the device and further improvements in the continuous production schemes were in detail considered.

\section{Requirements for finished products}

Product name is novolac phenol-formaldehyde oligomer (novolac) (table 1).<smiles>Cc1cccc(Cc2ccccc2O)c1O</smiles>

The average molecular weight is $730,86 \mathrm{~g} / \mathrm{mol}$

Molecular formula is $\mathrm{C}_{42} \mathrm{H}_{42} \mathrm{O}_{7}$
The characteristics of the original sample:

1. The standard sample is approved in accordance with the established procedure.

2. The standard sample should be replaced by newly prepared and approved after 6 months.

3. Validity period, its extension and storage of the standard sample is estab-

Table 1

Characteristics of the final product

\begin{tabular}{l|l}
\multicolumn{1}{c|}{ Name of the indicator } & \multicolumn{1}{c}{ Norm } \\
\hline Appearance & $\begin{array}{l}\text { Glossy granules from light yellow to yellow color } \\
\text { with a small uniform opalescent inclusions }\end{array}$ \\
\hline Dropping point & $110-150{ }^{\circ} \mathrm{C}$ \\
\hline The percentage of free phenol & $2 \% \max$ \\
\hline The percentage of insoluble polymer & $0,2 \% \max$ \\
\hline Solubility & $\begin{array}{l}\text { Aromatic and aliphatic hydrocarbons, acetone, } \\
\text { ethanol, chloromethanes }\end{array}$
\end{tabular}

The requirements to raw materials

\begin{tabular}{l|l|l|l|l}
\multicolumn{1}{c|}{ Name } & \multicolumn{1}{|c|}{ Marking NTD } & Sort or article & \multicolumn{1}{|c}{ Indicator to check } & \multicolumn{1}{c}{ Note } \\
\hline Phenol & GOST 23519-93 & Marks A and B & $\begin{array}{l}\text { The crystallization } \\
\text { temperature is } \\
40,6^{\circ} \mathrm{C} \text { or more; the } \\
\text { percentage is } 96 \% \\
\text { or higher }\end{array}$ & $\begin{array}{l}\text { Chemical } \\
\text { reagent, }\end{array}$ \\
\hline $\begin{array}{l}\text { Formalin } \\
\text { STO 55778270-872- }\end{array}$ & $\begin{array}{l}\text { Intermediate } \\
\text { product }\end{array}$ & $\begin{array}{l}\text { Mass percentage } \\
50 \%\end{array}$ & $\begin{array}{l}\text { From the } \\
\text { methanol } \\
\text { oxidation line }\end{array}$ \\
\hline $\begin{array}{l}\text { Oxalic } \\
\text { acid }\end{array}$ & $\begin{array}{l}\text { TC 6-36-0204229- } \\
1047-91\end{array}$ & $98 \%$ & Mass percentage & Chemical reagent
\end{tabular}


lished according to "The instruction for selection, study, approvement, storage and consumption of standard samples" approved in accordance with the established procedure.

\section{Description of the technological process}

The production of novolac phenolformaldehyde oligomers is the multistage continuous process. The block scheme of technological process is shown in Fig.1, the technological scheme is shown in Fig.2. work

Checking and preparing equipment for

All equipment is periodically visually checked on the integrity of the coating of apparatus, the isolation valves, the lack of reaction mass. The tightness of the devices is checked by creatign 2 ATM pres- sure inside the reactor, the compressed air supply should be closed. Upon exposure of 10 minutes the pressure should not decrease. The operation of the mixers, the flow of steam to the casing are checked at idling. The devices of IA, control panel are inspected.

\section{TP-1. Preparation of raw materials}

The raw materials and intermediates adopted by the input control with the appropriate mark of quality are passed in the production (table 2). Periodically all

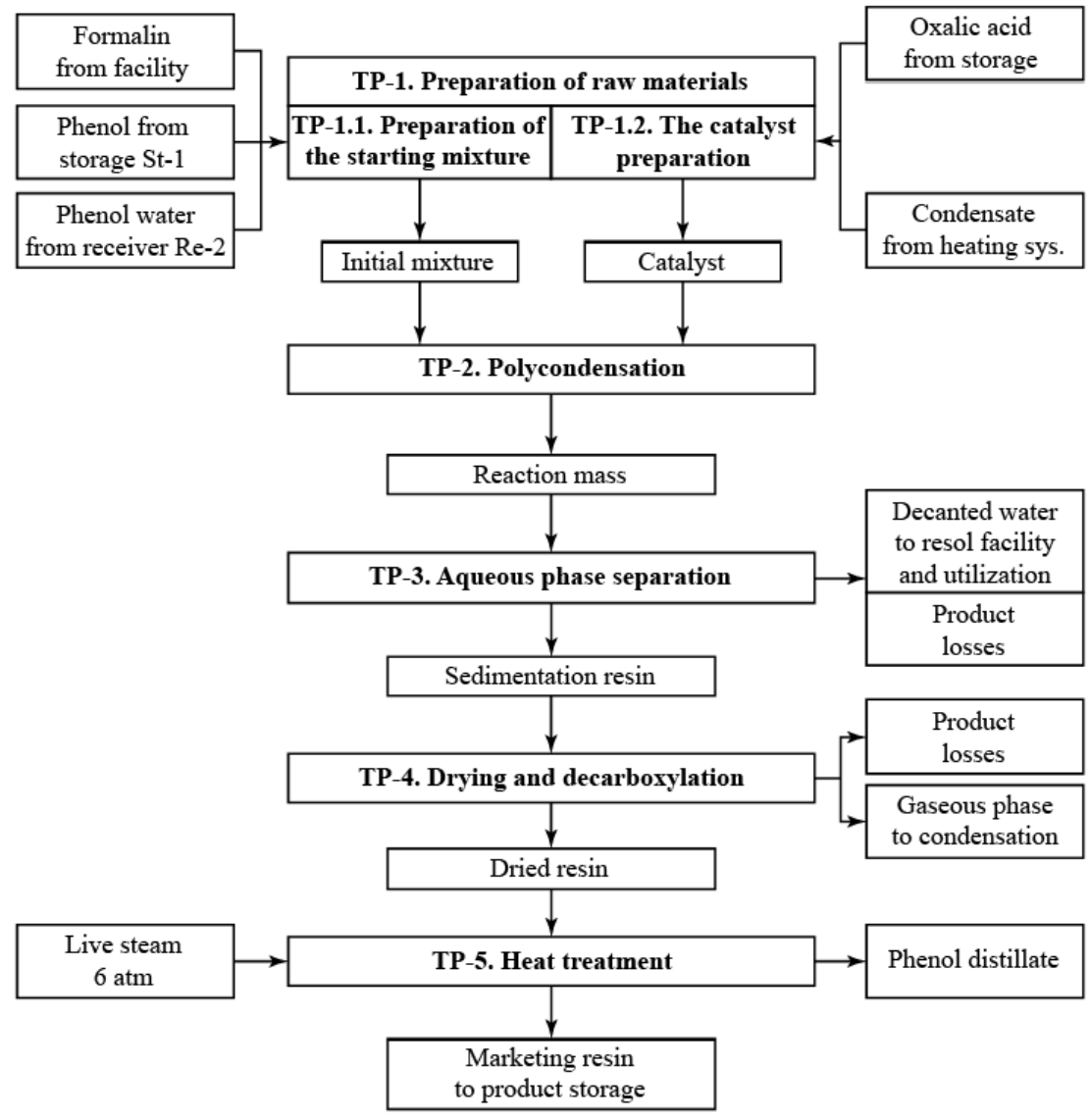

Fig. 1. Block scheme of technological process 


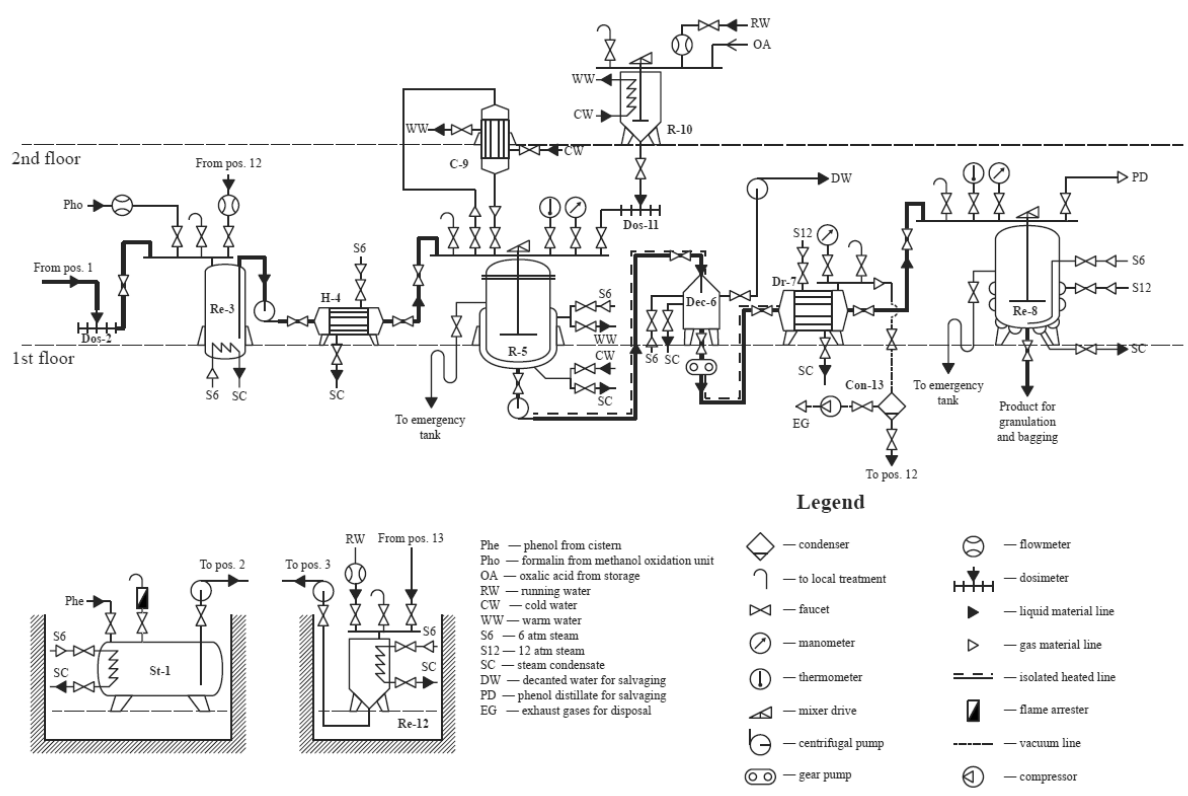

Fig. 2. Technological scheme of production

storages must fill out the appropriate raw materials.

TP-1.1. Preparation of the starting mixture

Apparatus design for stage:

1. Storage of phenol (St-1) is the apparatus, heated by tube bundle, made of steel $1 \mathrm{X} 18 \mathrm{H} 9 \mathrm{~T}$, with a capacity of $63 \mathrm{~m}^{3}$, connected with PC, equipped with the remote measuring glass.

2. Dosimeter of phenol (Dos-2) is the apparatus, heated by shirt, made of steel 1X18H9T, with capacity $40 \mathrm{~L}$, connected with PC, equipped with the remote measuring glass.

3. The mixing tank (Re-3) is the apparatus made of steel 1X18H9T, with a capacity of $1 \mathrm{~m}^{3}$, connected with $\mathrm{PC}$, equipped with the remote measuring glass. 4. The storage of phenolic water (Re-12) is the apparatus made of steel 1X18H9T, with a capacity of $25 \mathrm{~m}^{3}$, connected with $\mathrm{PC}$, equipped with the remote measuring glass and coil cooling.
5. Heater $(\mathrm{H}-4)$ is shell-and-tube apparatus made of steel $1 \mathrm{X} 18 \mathrm{H} 9 \mathrm{~T}$, with the cross section of the tube space $0,089 \mathrm{~m}^{2}$.

From the storage St-1 the molten phenol and the phenolic water recycling from the collector SB-12 is pumped to the dosimeter Dos-2, where it is periodically drained into the mixing tank Re-3, in which $50 \%$ formalin from the methanol oxidation facility is flowing continuously under the control of the flow meter. The mass resides in the mixer for 1.5 hours, continuously entering to the next stage through the heat exchanger $\mathrm{H}-4$ heated to $70{ }^{\circ} \mathrm{C}$ (table 3-4).

\section{TP-1.2. The catalyst preparation}

Apparatus design for stage:

1. Reactor for preparation of catalyst (R-10) is a apparatus made of steel $1 \mathrm{X} 18 \mathrm{H} 9 \mathrm{~T}$, with a capacity of $0.32 \mathrm{~m}^{3}$, connected with $\mathrm{PC}$, equipped with a remote measuring glass, thermometer, coil cooling and propeller stirrer. 
2. The dosimeter of the catalyst (Dos-11) is the apparatus made of steel 1X18H9T, with a capacity of $1 \mathrm{~L}$, connected with PC, equipped with a remote measuring glass.
Simultaneously with the preparation of the starting mixture, catalyst (an aqueous suspension of oxalic acid) is drained into the dosimeter Dos-11 from the reactor $\mathrm{R}-10$, which is loaded once per day by ox-

Table 3

Loaded on the stage TP-1.1

Loaded

\begin{tabular}{|c|c|c|c|c|}
\hline \multicolumn{2}{|r|}{ Raw materials and intermediates } & $\begin{array}{c}\text { content } \\
(\% \text { mass })\end{array}$ & $\begin{array}{c}\text { Technical mass, } \\
\text { kg/h } \\
\end{array}$ & $\begin{array}{c}\text { Mass } 100 \% \text {, } \\
\mathrm{kg} / \mathrm{h}\end{array}$ \\
\hline \multirow{3}{*}{1.} & Technical phenol, including & & 298,22 & \\
\hline & Phenol & 96,00 & & 286,29 \\
\hline & Impurities & 4,00 & & 11,93 \\
\hline \multirow{3}{*}{2.} & Formalin $50 \%$, including & & 166,74 & \\
\hline & Formaldehyde & 50,00 & & 83,37 \\
\hline & Water & 50,00 & & 83,37 \\
\hline \multirow{4}{*}{3.} & Phenol water, including & & 116,40 & \\
\hline & Phenol & 30,00 & & 34,92 \\
\hline & Formaldehyde & 3,85 & & 4,48 \\
\hline & Water & 66,15 & & 77,00 \\
\hline & Total: & & 581,36 & 581,36 \\
\hline
\end{tabular}

Obtained at the stage of TP-1.1

Table 4

Obtained

\begin{tabular}{|c|c|c|c|c|}
\hline \multicolumn{2}{|r|}{ Raw materials and intermediates } & $\begin{array}{c}\text { content } \\
\text { (\% mass) }\end{array}$ & $\begin{array}{c}\text { Mass techn., } \\
\mathrm{kg} / \mathrm{h}\end{array}$ & $\begin{array}{c}\text { Mass } 100 \% \text {, } \\
\mathrm{kg} / \mathrm{h}\end{array}$ \\
\hline \multirow{5}{*}{1.} & The initial mixture, including & & 581,36 & \\
\hline & Phenol & 55,25 & & 321,20 \\
\hline & impurities & 2,05 & & 11,93 \\
\hline & formaldehyde & 15,11 & & 87,85 \\
\hline & water & 27,59 & & 160,37 \\
\hline & Total: & & 581,36 & 581,36 \\
\hline
\end{tabular}

Uploaded on stages of TP-1.2

Table 5

Uploaded

\begin{tabular}{c|l|c|c|c}
\hline \multicolumn{2}{c|}{ Raw materials and intermediates } & $\begin{array}{c}\text { Content } \\
(\% \text { mass })\end{array}$ & $\begin{array}{c}\text { Mass techn., } \\
\mathrm{kg} / \mathrm{h}\end{array}$ & $\begin{array}{c}\text { Mass } \mathbf{1 0 0} \%, \\
\mathrm{~kg} / \mathrm{h}\end{array}$ \\
\hline \multirow{2}{*}{1.} & $\begin{array}{l}\text { Oxalic acid (technical quality), } \\
\text { including }\end{array}$ & & 3,09 & \\
\cline { 2 - 5 } & Oxalic acid & 95,50 & & 3,07 \\
\cline { 2 - 5 } & impurities & 0,50 & & 0,02 \\
\hline \multirow{2}{*}{ Total: } & water & & 7,21 & 7,21 \\
\hline \multicolumn{2}{l}{$\quad$} & $\mathbf{1 0 , 3 0}$ & $\mathbf{1 0 , 3 0}$
\end{tabular}


alic acid and water, which is then drained by gravity to the next stage. The addition of acid is regulated on the temperature and level of the mixture in the main reactor (table 5-6).

\section{TP-2. Polycondensation}

Apparatus design for stage:

1. The polycondensation reactor (R-5) is the apparatus made of steel 1X18H9T, with a capacity of $2 \mathrm{~m}^{3}$, connected with PC is supplied by a kinked pipe, level gauge, temperature and pressure gauges, plain jacket and anchor stirrer.

2. Backflow condenser (C-8) is shelland-tube apparatus made of 1X18H9T steel, with a cross section of the tube space $0,013 \mathrm{~m}^{2}$.

The original mixture and the catalyst are mixed, going into the main reactor $\mathrm{R}-5$ from the previous stage in a predeter- mined amount through the upper fittings, resulting in beginning of the chemical reaction of phenol and formaldehyde. The reaction takes place under the cooling of the reactor walls with water while maintaining a temperature of $98-100{ }^{\circ} \mathrm{C}$ for all time the mass stays in the apparatus (est. 2 hours), while it is continuously drained through the bottom fitting. The volatile starting materials evaporating in the reaction condense at the condenser C-8 and thus flow back to the reaction mass. Product samples are periodically taken from the reactor outlet. If the product becomes excessively viscous, the feed rate of the catalyst reduces.

The reactor is equipped with pipe displacement for an emergency evacuation of the mixture from the reactor. During the installation starting the primary quan-

Obtained at the stage of TP-1.2

Table 6

Obtained

\begin{tabular}{|c|c|c|c|c|}
\hline \multicolumn{2}{|r|}{ Raw materials and intermediates } & $\begin{array}{l}\text { Content } \\
(\% \text { mass })\end{array}$ & Mass techn., kg/h & $\begin{array}{c}\text { Mass } 100 \% \text {, } \\
\mathrm{kg} / \mathrm{h}\end{array}$ \\
\hline \multirow{4}{*}{1.} & Catalyst, including & & 10,30 & \\
\hline & Oxalic acid & 29,91 & & 3,07 \\
\hline & impurities & 0,10 & & 0,02 \\
\hline & Water & 69,99 & & 7,21 \\
\hline & Total: & & 10,30 & 10,30 \\
\hline
\end{tabular}

Table 7

Uploaded on stages of TP-2

\begin{tabular}{|c|c|c|c|c|}
\hline \multicolumn{2}{|r|}{ Raw materials and intermediates } & $\begin{array}{l}\text { Content } \\
\text { (\% mass) }\end{array}$ & $\begin{array}{c}\text { Mass techn., } \\
\mathrm{kg} / \mathrm{h}\end{array}$ & $\begin{array}{c}\text { Mass } 100 \% \text {, } \\
\mathrm{kg} / \mathrm{h}\end{array}$ \\
\hline \multirow{5}{*}{1.} & The initial mixture, including & & 581,36 & \\
\hline & Phenol & 55,25 & & 321,20 \\
\hline & Impurities & 2,05 & & 11,93 \\
\hline & Formaldehyde & 15,11 & & 87,85 \\
\hline & Water & 27,59 & & 160,37 \\
\hline \multirow{4}{*}{2.} & Catalyst, including & & 10,30 & \\
\hline & Oxalic acid & 29,91 & & 3,07 \\
\hline & Impurities & 0,10 & & 0,02 \\
\hline & Water & 69,99 & & 7,21 \\
\hline & Total: & & 591,66 & 591,66 \\
\hline
\end{tabular}


tity of the initial mixture is heated by dead steam (6 ATM) to reaction temperature and only then the water could be let in a jacket (table 7-8).

TP-3. Aqueous phase separation

Apparatus design for stage:

1. Florentine vessel (Dec-6) is a apparatus made of steel 1X18H9T, with a capacity of $2 \mathrm{~m}^{3}$, connected with $\mathrm{PC}$, equipped with a sight glass and a plain jacket.

The obtained mixture of the product, precursors and formed water from the reactor R-5 is fed to a continuous sedimentation in a steam-heated (6 bar) florentine vessel Dec-6. The mixture in the vessel is separated into aqueous and organic phase; the first is drained through the upper fitting and is led to utilization or resol resins production, the second is compressed with gear pump to the drying stage through the lower fitting (table 9-10).

TP - 4. Drying and decarboxylation

Apparatus design for stage:

1. Dryer (Dr-7) is shell-and-tube apparatus made of $1 \mathrm{X} 18 \mathrm{H} 9 \mathrm{~T}$ steel, with a cross section of the tube space $0,259 \mathrm{~m}^{2}$, equipped by vacuum manometer at the outlet from tube space.

The resin is pumped from the separation stage into the dryer Dr-7, made in the form of shell-and-tube exchanger heated by high pressure steam (12 ATM) to create a temperature of $140-180{ }^{\circ} \mathrm{C}$. The resin is fed into the tubular space, where the medium vacuum is created, and moves in the form of a film due to the

Table 8

Obtained at the stage of TP-2

Obtained

\begin{tabular}{|c|c|c|c|c|}
\hline \multicolumn{2}{|r|}{ Raw materials and intermediates } & $\begin{array}{l}\text { Content } \\
\text { (\% mass) }\end{array}$ & $\begin{array}{c}\text { Mass techn., } \\
\mathrm{kg} / \mathrm{h}\end{array}$ & $\begin{array}{c}\text { Mass } 100 \%, \\
\mathrm{~kg} / \mathrm{h}\end{array}$ \\
\hline \multirow{7}{*}{1.} & Reaction mass, including & & 591,66 & \\
\hline & PFO & 49,99 & & 295,77 \\
\hline & Phenol & 9,23 & & 54,60 \\
\hline & Impurities & 2,02 & & 11,93 \\
\hline & Water & 35,72 & & 211,33 \\
\hline & Oxalic acid & 0,52 & & 3,07 \\
\hline & Formaldehyde & 2,52 & & 14,93 \\
\hline & Total: & & 591,66 & 591,66 \\
\hline
\end{tabular}

Uploaded on stage of TP-3

Table 9

Uploaded

\begin{tabular}{|c|c|c|c|c|}
\hline \multicolumn{2}{|r|}{ Raw materials and intermediates } & $\begin{array}{l}\text { Content } \\
\text { (\% mass) }\end{array}$ & $\begin{array}{c}\text { Mass techn., } \\
\text { kg/h }\end{array}$ & $\begin{array}{c}\text { Mass } 100 \% \text {, } \\
\mathrm{kg} / \mathrm{h}\end{array}$ \\
\hline \multirow{7}{*}{1 . } & Reaction mass, including & & 591,66 & \\
\hline & $\mathrm{PFO}$ & 49,99 & & 295,77 \\
\hline & Phenol & 9,23 & & 54,60 \\
\hline & Impurities & 2,02 & & 11,93 \\
\hline & Water & 35,72 & & 211,33 \\
\hline & Oxalic acid & 0,52 & & 3,07 \\
\hline & Formaldehyde & 2,52 & & 14,93 \\
\hline & Total: & & 591,66 & 591,66 \\
\hline
\end{tabular}


Obtained at the stage TP-3

Obtained

\begin{tabular}{|c|c|c|c|c|}
\hline \multicolumn{2}{|r|}{ Raw materials and intermediates } & $\begin{array}{l}\text { Content } \\
\text { (\% mass) }\end{array}$ & $\begin{array}{c}\text { Mass techn., } \\
\mathrm{kg} / \mathrm{h}\end{array}$ & $\begin{array}{c}\text { Mass } 100 \% \text {, } \\
\mathrm{kg} / \mathrm{h}\end{array}$ \\
\hline \multirow{6}{*}{1 . } & Sedimentation resin, including & & 417,10 & \\
\hline & $\mathrm{PFO}$ & 70,84 & & 295,48 \\
\hline & Phenol & 11,39 & & 47,51 \\
\hline & Oxalic acid & 0,74 & & 3,07 \\
\hline & Formaldehyde & 1,07 & & 4,48 \\
\hline & Water & 15,96 & & 66,57 \\
\hline \multirow{6}{*}{2.} & Decanted water, including & & 174,56 & \\
\hline & Water & 75,27 & & 144,76 \\
\hline & Phenol & 5,62 & & 7,10 \\
\hline & Formaldehyde & 8,28 & & 10,45 \\
\hline & Impurities & 10,61 & & 110,93 \\
\hline & $\mathrm{PFO}$ & 0,23 & & 0,30 \\
\hline & Total: & & 591,66 & 591,66 \\
\hline
\end{tabular}

Table 11

Uploaded on stage of TP-4

Uploaded

\begin{tabular}{|c|c|c|c|c|}
\hline & Raw materials and intermediates & $\begin{array}{l}\text { Content } \\
\text { (\% mass) }\end{array}$ & $\begin{array}{c}\text { Mass techn., } \\
\mathrm{kg} / \mathrm{h}\end{array}$ & $\begin{array}{c}\text { Mass } 100 \% \text {, } \\
\mathrm{kg} / \mathrm{h}\end{array}$ \\
\hline \multirow{6}{*}{1 . } & Sedimentation resin, including & & 417,10 & \\
\hline & $\mathrm{PFO}$ & 70,84 & & 295,48 \\
\hline & Phenol & 11,39 & & 47,51 \\
\hline & Oxalic acid & 0,74 & & 3,07 \\
\hline & Formaldehyde & 1,07 & & 4,48 \\
\hline & Water & 15,96 & & 66,57 \\
\hline & Total: & & 417,10 & 417,10 \\
\hline
\end{tabular}

Table 12

Obtained at the stage TP-4

\begin{tabular}{|c|c|c|c|c|}
\hline \multicolumn{5}{|c|}{ Obtained } \\
\hline \multicolumn{2}{|r|}{ Raw materials and intermediates } & $\begin{array}{l}\text { Content } \\
(\% \text { mass })\end{array}$ & $\begin{array}{c}\text { Mass techn., } \\
\mathrm{kg} / \mathrm{h}\end{array}$ & $\begin{array}{c}\text { Mass } 100 \% \text {, } \\
\mathrm{kg} / \mathrm{h}\end{array}$ \\
\hline \multirow{3}{*}{1.} & Dried resin, including & & 306,59 & \\
\hline & $\mathrm{PFO}$ & 95,89 & & 294,00 \\
\hline & Phenol & 4,11 & & 12,59 \\
\hline 2. & Loss & & 1,48 & 1,48 \\
\hline \multirow{6}{*}{3.} & Gaseous phase, including & & 109,04 & \\
\hline & Water & 61,05 & & 67,18 \\
\hline & Formaldehyde & 4,11 & & 4,48 \\
\hline & Carbon dioxide gas & 1,38 & & 1,50 \\
\hline & Carbon monoxide gas & 0,88 & & 0,96 \\
\hline & Phenol & 32,58 & & 34,92 \\
\hline & Total: & & 417,10 & 417,10 \\
\hline
\end{tabular}


evaporation of the volatile components and gaseous products of oxalic acid decomposing during the process. The dried resin is then fed to the next stage and the gaseous phase goes to condensation and the phenolic water formation to the collector Re-12 (table 11-12).

Uploaded on stage of TP-5

Table 13

Uploaded

\begin{tabular}{|c|c|c|c|c|}
\hline \multicolumn{2}{|r|}{ Raw materials and intermediates } & $\begin{array}{l}\text { Content } \\
\text { (\% mass) }\end{array}$ & $\begin{array}{c}\text { Mass techn., } \\
\mathrm{kg} / \mathrm{h}\end{array}$ & $\begin{array}{c}\text { Mass } 100 \% \text {, } \\
\mathrm{kg} / \mathrm{h}\end{array}$ \\
\hline \multirow{3}{*}{1.} & Dried resin, including & & 306,59 & \\
\hline & $\mathrm{PFO}$ & 95,89 & & 294,00 \\
\hline & Phenol & 4,11 & & 12,59 \\
\hline \multirow{2}{*}{\multicolumn{2}{|c|}{$\frac{\text { Live steam }}{\text { Total: }}$}} & & 359,89 & 359,89 \\
\hline & & & 666,47 & 666,47 \\
\hline
\end{tabular}

Table 14

Obtained at the stage TP- 5

Получено

\begin{tabular}{l|l|c|c|c}
\hline \multicolumn{2}{c|}{ Raw materials and intermediates } & $\begin{array}{c}\text { Content } \\
\text { (\% mass) }\end{array}$ & $\begin{array}{c}\text { Mass techn., } \\
\mathbf{k g} / \mathbf{h}\end{array}$ & $\begin{array}{c}\text { Mass 100 \%, } \\
\mathbf{~ k g} / \mathbf{h}\end{array}$ \\
\hline \multirow{3}{*}{1.} & & 299,99 & \\
\cline { 2 - 5 } & Marketable resin, including & 98,00 & & 294,00 \\
\hline & Phenol & 2,00 & & 5,99 \\
\hline \multirow{2}{*}{2.} & Phenol distillate, including & & 366,48 & \\
\cline { 2 - 5 } & Phenol Total: & 1,80 & & 6,60 \\
\hline & Water & 98,20 & & 359,89 \\
\hline & & 666,47 & 666,47
\end{tabular}

Table 15

Main technological parameters and production control

\begin{tabular}{|c|c|c|c|c|}
\hline Control point & $\begin{array}{l}\text { The name of the } \\
\text { object of control }\end{array}$ & $\begin{array}{c}\text { Controlled } \\
\text { parameter and } \\
\text { dimension }\end{array}$ & Normative & $\begin{array}{l}\text { The method } \\
\text { and means of } \\
\text { control }\end{array}$ \\
\hline $\begin{array}{l}\text { Reactor R-5, } \\
\text { CP-1 }\end{array}$ & Reaction mass & Temperature, ${ }^{\circ} \mathrm{C}$ & $\begin{array}{l}\text { Less than } \\
100^{\circ} \mathrm{C} \\
\text { more than } \\
97^{\circ} \mathrm{C} \\
\end{array}$ & $\begin{array}{c}\text { The sensor } \\
\text { output on the } \\
\text { shield }\end{array}$ \\
\hline $\begin{array}{c}\text { Reactor R-5, } \\
\text { CP-2 }\end{array}$ & Reaction mass & Viscosity, $\mathrm{MPa}$ & Less than 1200 & Laboratory \\
\hline Dryer D-7, CP-3 & Work regime & Vacuum, ATM & 0,3 & $\begin{array}{l}\text { The vacuum } \\
\text { gauge output }\end{array}$ \\
\hline $\begin{array}{l}\text { Resin collector, } \\
\text { CP-4 }\end{array}$ & Reaction mass & $\begin{array}{c}\text { Dropping } \\
\text { temperature, }{ }^{\circ} \mathrm{C}\end{array}$ & $\begin{array}{c}\text { Depends on } \\
\text { the brand of } \\
\text { oligomer }\end{array}$ & $\begin{array}{l}\text { Laboratory, } \\
\text { according to } \\
\text { the Ubbelohde } \\
\text { method }\end{array}$ \\
\hline $\begin{array}{l}\text { Resin collector, } \\
\text { CP-4 }\end{array}$ & Mass output & $\begin{array}{l}\text { The content of } \\
\text { phenol, \% }\end{array}$ & Less than 2 & Laboratory \\
\hline
\end{tabular}


Because of high pressure steam heating, the polymerized resin remains on the tubes and must be periodically removed.

\section{TP-5. Heat treatment}

Apparatus design for stage:

1. Resin collector (Re-8) is the apparatus made of steel $1 \mathrm{X} 18 \mathrm{H} 9 \mathrm{~T}$, with a capacity of $2 \mathrm{~m}^{3}$, connected with PC, is supplied by a kinked pipe, tank gauge, temperature and pressure gauges, coil semi-tube jacket and anchor stirrer.

The molten dried resin is poured into resin collector Re-8, a capacitive apparatus with jacket and mixer. Resin is fed to a predetermined filling level after which the incoming stream is transferred to another resin collector, and the live steam (6 bar) is flown to the apparatus through the kinked pipe. Under heating by both live and dead steam (12 bar) the temperature is maintained in the range of $130-190^{\circ} \mathrm{C}$, resulting in the excess phenol steam-distilling and going to condensation and disposal. Samples are collected periodically from the apparatus to verify compliance with standardized parameters. After the process is finished the marketable resin is supplied to the granulation and bagging (table 13-14).

\section{Conclusion}

This paper presents the modification of the technological scheme of production of novolac phenol-formaldehyde oligomers. Analytical review presents brief characteristics of raw materials, starting materials and the impact of each type of phenol and formaldehyde raw materials on technological and physicomechanical properties of the product. In the technological part the characteristic of finished products, raw materials and materials are given, a detailed description of technology and technological scheme of production is shown (table 15).

\section{In Russian}

\section{Введение}

Фенолформальдегидные олигомеры относятся к первым пластическим массам, полученным реакцией поликонденсации. Их получают из фенолов и альдегидов, преимущественно формальдегида. В качестве фенольного сырья наряду с фенолом используют крезолы, ксиленолы, многоатомные фенолы, алкилфенолы, многоядерные соединения, например бисфенол и др. В зависимости от соотношения реагентов и способа катализа различают новолаки (избыток фенолов с катализом кислотами) и резолы (избыток формальдегида с катализом щелочами).
В эпоху бурного развития пластмасс трудно дать прогноз относительно будущего фенолформальдегидных олигомеров - наиболее старых полимерных материалов. Однако с уверенностью можно сказать, что и в настоящее время они не только не утратили своего значения, но и есть основания рассчитывать на долгосрочный, хотя и незначительный абсолютный рост производства фенопластов, несмотря на снижение их относительной доли в общем объеме выпуска пластмасс.

Фенолформальдегидные олигомеры были первыми промышленными синтетическими реактопластами. Тол- 
чком к их производству послужил как дефицит природного сырья, так и необходимость замены природных материалов синтетическими.

Примечателен тот факт, что так называемые классические фенолформальдегидные реактопласты и термопласты, несмотря на снижение их удельной доли в мировом производстве пластмасс, не только не уступили своих позиций, а, наоборот, приобрели гораздо большее значение. В связи с этим, а также со значительно ужесточившимися экологическими нормами, требуется поиск наиболее экономичной и экологичной технологии производства фенолформальдегидных олигомеров, в частности новолаков, чему и посвящена данная работа.

Краткая характеристика и основнье области применения фенолформальдегидных новолачных олигомеров

Цвет неотвержденных олигомеровот светло-желтого до темно-коричневого; средняя молекулярная масса 400-1000 г/моль, плотность расплавов-

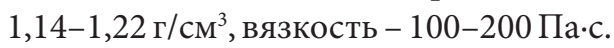
Плотность твердых смол -1,221,27 г/ $\mathrm{cm}^{3}$, температура каплепадения по Уббелоде - 70-130 ㄷ. Неотвержденные олигомеры растворимы в фенолах и растворах щелочей, в органических растворителях [1].

При длительном контакте с водой отвержденные олигомеры подвержены частичному набуханию, в органических растворителях практически не растворимы, хотя содержащиеся в них олигомеры могут быть частично извлечены экстракцией. При воздействии водных растворов щелочей или фенольных расплавов резиты медленно растворяются с разложением.
Они стойки к действию большинства кислот, за исключением концентрированной серной и кислот-окислителей.

При полной или частичной замене фенола на крезол или ксиленол олигомеры после отверждения отличаются улучшенными диэлектрическими свойствами.

Свойства наполненных олигомеров в значительной мере обусловлены самим наполнителем.

Отвержденные олигомеры длительное время стабильны при нагревании до $200{ }^{\circ} \mathrm{C}$ и ограниченно способны противостоять действию более высоких температур (сутки при 200-250 ${ }^{\circ} \mathrm{C}$, часы при 250-500 ${ }^{\circ} \mathrm{C}$, минуты при 500-1000 ${ }^{\circ} \mathrm{C}$, несколько секунд при $\left.1000-1500{ }^{\circ} \mathrm{C}\right)$. Разложение отвержденных олигомеров начинается при температуре около $300{ }^{\circ} \mathrm{C}$ и сопровождается выделением продуктов пиролиза (гомологов фенола и бензола, углекислого газа и др.). Окислители и кислоты ускоряют этот процесс. При более высоких температурах происходит обугливание с образованием кокса. Наличие заместителей в фенольных ядрах снижает термостойкость смол: олигомеры, полученные из алкилфенолов, начинают быстро разлагаться уже при $230{ }^{\circ} \mathrm{C}$.

\section{Основные области применения $\Phi \Phi O[2]:$}

Пенопласты и пеноблоки

Получаются путем газонаполнения углеводородами резолов с наполнителями (технология аналогична производству пенополистирола); используются в качестве тепло- и звукоизоляционного материала, обладающего повышенной термостабильностью и пожаростойкостью по сравнению с ППС. 
Клеи и адгезивные материаль

Широкое распространение получили клеи на основе фенолформальдегидных смол, предназначенные для связывания древесных волокон (матрицы ДВП, ДСП, фанеры). Вязкие ФФО применяются для холодной сварки легких металлов и пластиковых изделий (например, для сшивания линолеума), составы на их основе при модификации способны работать в экстремальных условиях; их растворы в этаноле и прочих летучих растворителях применяются в качестве медицинского клея для заживления ран.

\section{Пресс-массы}

Прессованные порошки используются как для отливки готовых изделий (все реже в последние годы), так и для составления композитных материалов с различными наполнителями; широко применяются в составе строительных смесей для создания покрытий или адгезивных слоев.

\section{Лаковые смолы}

Используются как замена природному шеллаку, в качестве диэлектрических покрытий и защиты металлов от коррозии. В настоящее время все большее применение находит «жидкий новолак», представляющий собой раствор новолака в этиленгликоле, который используется как антикоррозионное покрытие в судостроении.

\section{Слоистые пластики}

Композиты на основе фенолформальдегидного олигомера, использующиеся в качестве легкого прочного материала для облегчения конструкции, а также как материалы, стойкие к неблагоприятным условиям и обладающие при этом хорошими диэлектрическими свойствами. Используются также для формования труб и стержней различных типов.

Ионообменные смоль

К ионообменным смолам на основе ФФО относится практически весь спектр катионных, анионных, амфотерных и других смол, содержащих в своей основе ароматический мономер ряда бензола. Данные смолы широко используются при очистке стоков, водоподготовке и катализе в химической промышленности.

Краткая харакетристика сырья, применяемого в производстве фенолформальдегидных новолачньх олигомеров

Фенол<smiles>Oc1ccccc1</smiles>

Бесцветное кристаллическое вещество с характерным запахом гуаши, т. пл. $-40,9^{\circ} \mathrm{C}$, т. кип. $-181,8^{\circ} \mathrm{C}$, плотность - около 1030 кг/м³. На воздухе, окисляясь, фенол приобретает розовую окраску. Примеси значительно снижают температуру плавления фенола. Растворимость в воде около 8 \%, при нагревании до $84{ }^{\circ} \mathrm{C}$ смешивается с водой в любых отношениях. Водные растворы щелочей легко растворяют фенол с образованием фенолятов. Фенол растворим в формалине, этаноле, диэтиловом эфире, глицерине, бензоле, скипидаре, жирных кислотах и их эфирах [2].

Химическая активность фенола при синтезе фенолоальдегидных смол обусловлена наличием в его молекуле трех подвижных протонов - двух в орто- и одного в пара-положении к гидроксильной группе.

Крезоль (метилфеноль) 
<smiles>Cc1ccccc1O</smiles><smiles>Cc1cccc(O)c1</smiles><smiles>Cc1ccc(O)cc1</smiles>

Фенолы присоединяют формальдегид лишь в орто- и пара-положения к гидроксильной группе, поэтому наибольшей функциональностью обладает $\mathcal{M}$-крезол, имеющий три активных протона и образующий термореактопласты; о- и п-крезолы, являющиеся лишь бифункциональными, дают термопласты.

Ввиду трудности разделения крезолов часто применяется смесь трех изомеров, называемая трикрезолом: жидкость плотностью 1044 кг/м³ кипящая в интервале $185-205^{\circ} \mathrm{C}$ в зависимости от содержания изомеров и примесей. Трикрезол растворим в этаноле, диэтиловом эфире и щелочных раствоpax, в воде растворяется около 2,5 \% трикрезола. Для получения трикрезола используют фракцию каменноугольной смолы, кипящую в пределах $160-250{ }^{\circ} \mathrm{C}$, которую очищают от большей части нафталина.

Ксиленоль (диметилфеноль)<smiles>Cc1ccc(O)c(C)c1</smiles>

Ксиленол существует в виде шести изомеров. Технический ксиленол смесь изомеров - вязкое масло коричнево-черного цвета с сильным неприятным запахом, т. кип. - 200-220 ${ }^{\circ} \mathrm{C}$, плотность - 1040 кг/ $\mathrm{M}^{3}$, растворяется в 10 \%-м водном растворе щелочи. Основным источником получения ксиленола являются крезольные фракции смол, образующихся при термической обработке топлив. Ввиду бифункциональности не способен образовывать сетчатую структуру и без введения дополнительного сырья пригоден только для получения термопластичных олигомеров.

Бисбенол А и его производные<smiles>CC(C)(c1ccc(O)cc1)c1ccc(O)cc1</smiles>

Продукты конденсации фенолов и ацетона при катализе минеральными кислотами. Обладают несколькими активными центрами (вплоть до 4), как следствие, способны сшивать олигомерные цепи при добавлении к основному сырью для повышения термостойкости и жесткости.

Фурфуриловыци спирт<smiles>OCc1ccco1</smiles>

Производное фурфурола, повышающее термореактивные свойства и вязкость полимера; обладает высокоактивным центром в положении 5 фуранового цикла.

Хлорфеноль

Моно-, ди- и тризамещенные продукты хлорирования фенола. Обладают меньшей активностью, чем фенолы и крезолы, но большей кислотностью и при этом придают готовому продукту повышенную стойкость к горению ввиду наличия атомов хлора.

\section{Высшие феноль}

К данной группе относятся гидроксинафталины, фенольные производные антраценов, фенантренов и т. д. При добавке к олигомерам придают им высокую термостойкость (вплоть до $\left.400{ }^{\circ} \mathrm{C}\right)$, возрастающую с увеличе- 
нием числа конденсированных циклов в фенолах.

\section{Формалин}

Водный раствор формальдегида концентрацией до 37 \% при комнатной температуре или до 50 \% при повышенной. При реакции с фенолами вступает в электрофильное ароматическое присоединение, «сшивая» между собой ароматические ядра и тем самым образуя олигомеры. В качестве замены нестабильному раствору на производстве иногда используются твердые производные формальдегида - параформ и уротропин.

\section{Лигнин}

Природный олигомер, являющийся составной частью древесины. Представляет собой фенольные центры, сшитые насыщенными углеводородными цепями (до 3-4 атомов). Олигомер, полученный с использованием лигнина, содержит меньшее количество свободного фенола, а также является в значительной степени биоразлагаемым, что облегчает его утилизацию и наносит меньший вред окружающей среде. Производство олигомеров на базе лигнина в настоящий момент приобретает все большую значимость в развитых странах в связи с ужесточением экологических норм.

Новолачные фенолоформальдегидные олигомеры получают, как правило, поликонденсацией фенола и формальдегида (в виде формалина) в кислой водной среде; различные добавки к исходному сырью имеют лишь ограниченное применение. Производство ведется по периодической либо непрерывной схеме [3]. В данной работе подробно рассмотрено устройство и дальнейшее усовершенствование непрерывной схемы производства.

\section{Требования к готовой продукции}

Наименование продукта: новолачный фенолоформальдегидный олигомер (новолак) (табл. 1).<smiles>CCc1ccccc1Cc1ccccc1O</smiles>

Средняя молекулярная масса: 730,86 г/моль
Брутто-формула: $\mathrm{C}_{42} \mathrm{H}_{42} \mathrm{O}_{7}$

Характеристика исходного образца:

1. Стандартный образец утверждается в соответствующем порядке.

2. Стандартный образец подлежит замене вновь приготовленным и утвержденным через 6 месяцев.

3. Срок действия, продления и хранение стандартного образца устанавли-

Таблица 1

Характеристика конечного продукта

\begin{tabular}{l|l}
\multicolumn{1}{c|}{ Наименование показателя } & \multicolumn{1}{c}{ Норма } \\
\hline Внешний вид & $\begin{array}{l}\text { Глянцевые гранулы от светло-желтого до желтого } \\
\text { цвета с мелкими равномерными опалесцирующими } \\
\text { включениями }\end{array}$ \\
\hline Температура каплепадения & $110-150^{\circ} \mathrm{C}$ \\
\hline Содержание свободного фенола & Не более $2 \%$ \\
\hline Доля нерастворимого полимера & Не более 0,2 \% \\
\hline Растворимость & $\begin{array}{l}\text { Ароматические и алифатические УВ, ацетон, } \\
\text { этанол, хлорпроизводные метана }\end{array}$
\end{tabular}


вается в соответствии с «Инструкцией тных образцов», утвержденных в устапо отбору, испытанию, утверждению, новленном порядке.

хранению и расходованию стандар-

Таблица 2

Требования к сырью

\begin{tabular}{|c|c|c|c|c|}
\hline Наименование & $\begin{array}{c}\text { Обозначение } \\
\text { НТД }\end{array}$ & $\begin{array}{c}\text { Сорт или } \\
\text { артикул }\end{array}$ & $\begin{array}{c}\text { Показатель для } \\
\text { проверки } \\
\end{array}$ & Примечание \\
\hline Фенол & ГОСТ 23519-93 & $\begin{array}{l}\text { Марки А } \\
\text { и Б }\end{array}$ & $\begin{array}{l}\text { Температура кри- } \\
\text { сталлизации } 40,6{ }^{\circ} \mathrm{C} \\
\text { и более; содержание } \\
\text { не менее } 96 \%\end{array}$ & $\begin{array}{l}\text { Химический } \\
\text { реактив }\end{array}$ \\
\hline Формалин & $\begin{array}{l}\text { CTO 55778270- } \\
872-2009\end{array}$ & $\begin{array}{l}\text { Полупро- } \\
\text { дукт }\end{array}$ & Массовая доля 50 \% & $\begin{array}{l}\text { С цеха окисле- } \\
\text { ния метанола }\end{array}$ \\
\hline $\begin{array}{l}\text { Щавелевая } \\
\text { кислота }\end{array}$ & $\begin{array}{l}\text { ТУ 6-36-0204229- } \\
1047-91\end{array}$ & $98 \%$ & Массовая доля & $\begin{array}{l}\text { Химический } \\
\text { реактив }\end{array}$ \\
\hline
\end{tabular}

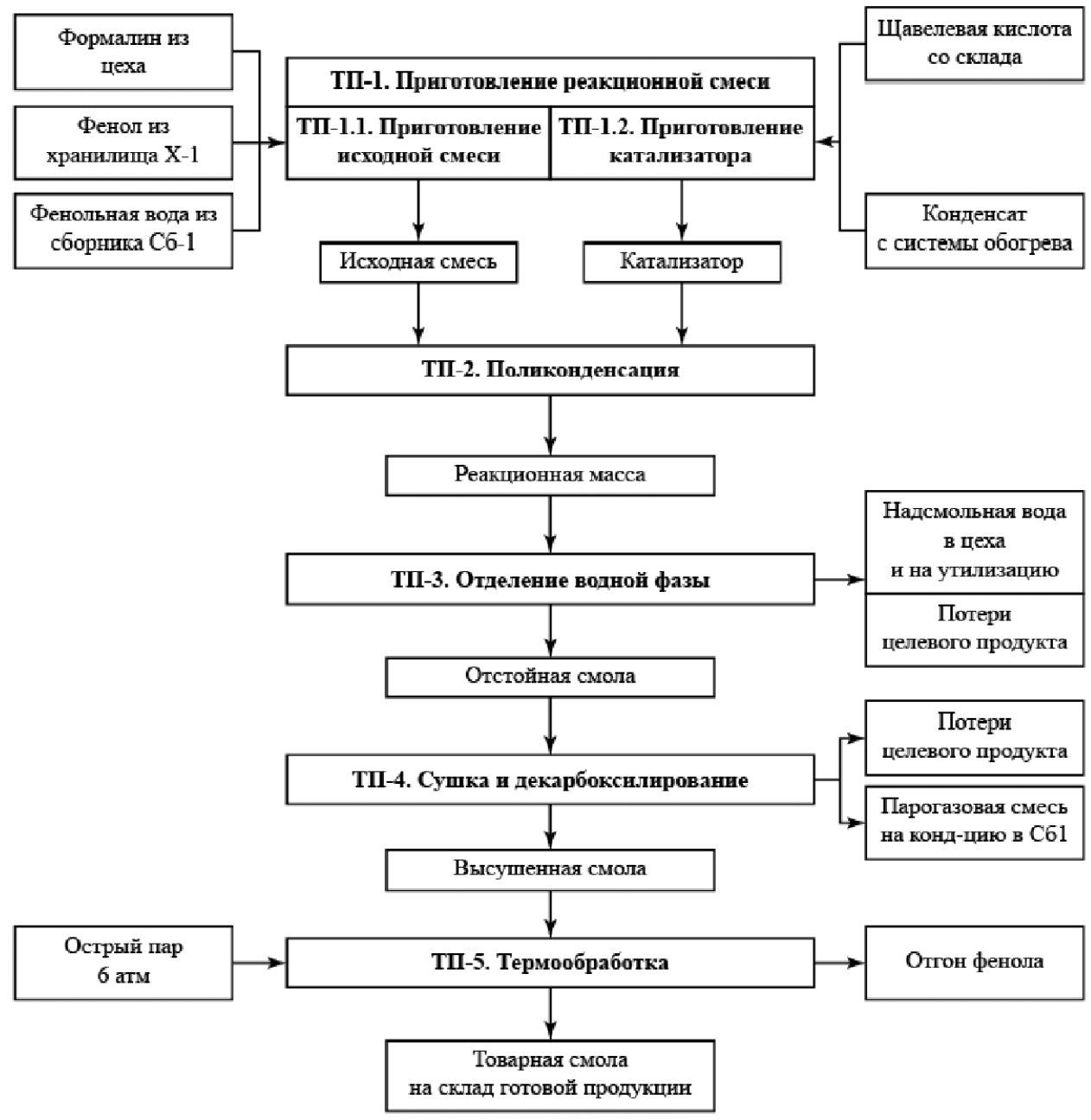

Рис. 1. Блок-схема технологического процесса 


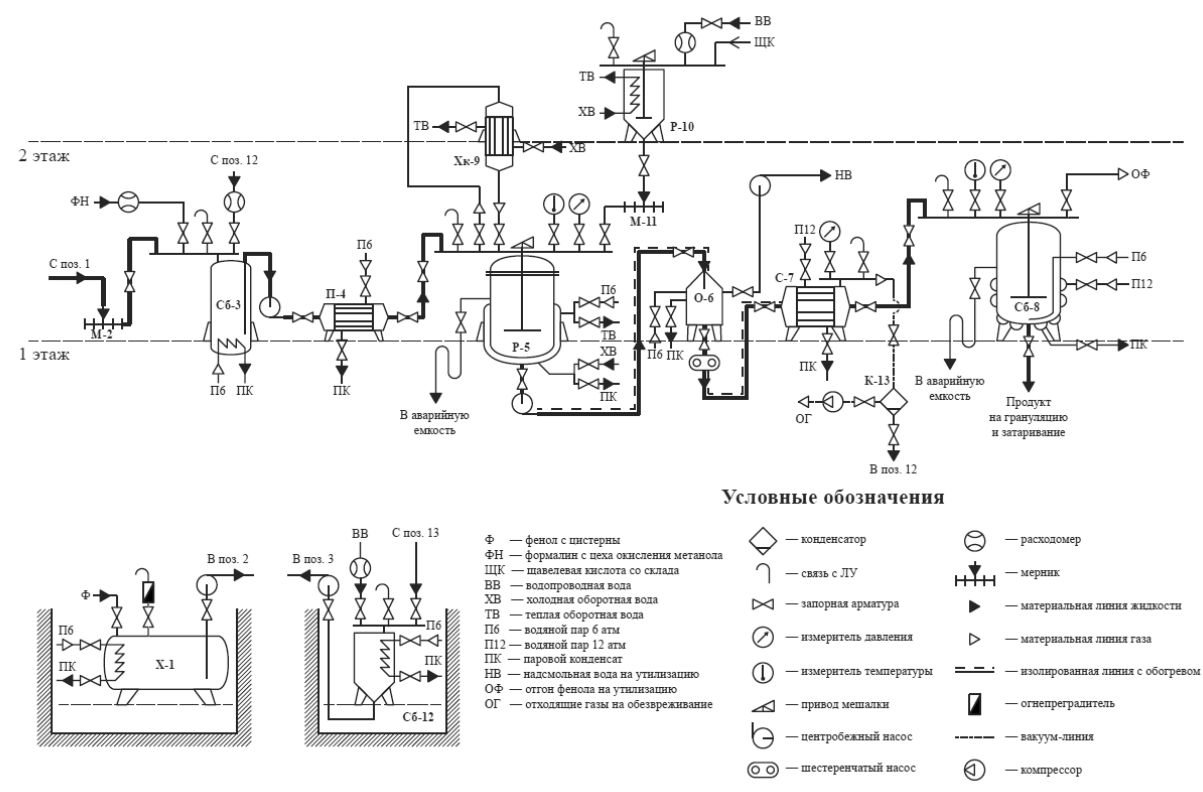

Рис. 2. Технологическая схема производства

\section{Описание технологического процесса}

Производство новолачного фенолформальдегидного олигомера является многостадийным непрерывным процессом. Блок-схема технологического процесса представлена на рис. 1, технологическая схема - на рис. 2.

Проверка и подготовка к работе оборудования

Bce оборудование периодически визуально проверяют на целостность покрытия аппарата, запорной арматуры, отсутствие реакционной массы. Герметичность аппаратов проверяют созданием давления 2 атм внутри реактора, закрывают подачу сжатого воздуха. При выдержке 10 мин давление не должно уменьшиться. На холостом ходу проверяют работу мешалок, поступление пара в рубашки. Контролируют приборы КИПиА, пульт управления.

\section{Подготовка сырья}

В производство передается сырье и полупродукты, принятые входным контролем с соответствующей отметкой о качестве (табл. 2). Периодически все хранилища заполняют соответствующим сырьем.

ТП-1.1. Приготовление исходной смеси

Аппаратурное оформление стадии:

1. Хранилище фенола (X-1) аппарат, обогреваемый пучком труб, из стали $1 \mathrm{X} 18 \mathrm{H} 9 \mathrm{~T}$, вместимостью $63 \mathrm{~m}^{3}$, скоммуницирован с ЛУ, снабжен выносным мерным стеклом.

2. Мерник фенола (М-2) - аппарат, обогреваемый рубашкой, из стали 1Х18Н9Т, вместимостью 40 л, скоммуницирован с ЛУ, снабжен выносным мерным стеклом.

3. Смесительная емкость (Сб-3) аппарат из стали 1X18Н9T, вмести- 
мостью 1 м 3 , скоммуницирован с ЛУ, снабжен выносным мерным стеклом.

4. Сборник фенольной воды (Сб-12) - аппарат из стали 1 Х18Н9Т, вместимостью $25 \mathrm{~m}^{3}$, скоммуницирован с ЛУ, снабжен выносным мерным стеклом и змеевиковым охлаждением.

5. Подогреватель (П-4) - кожухотрубный аппарат из стали 1Х18Н9T, с сечением трубного пространства $0,089 \mathrm{M}^{2}$.

Из хранилища X-1 перекачивается расплав фенола в мерник М-2, откуда периодически сливается в смесительную емкость Сб-3, в которую непрерывно под контролем расходомера поступают формалин 50 \% с цеха окисления метанола и фенольная вода с рецикла из сборника Сб-12. В смесителе масса пребывает 1,5 ч, непрерывно перекачиваясь на следующую стадию через теплообменник П-4 для подогрева до $70{ }^{\circ} \mathrm{C}$ (табл. 3-4).

ТП-1.2. Приготовление катализаTopa

Аппаратурное оформление стадии:

1. Реактор приготовления катализатора (Р-10) - аппарат из стали 1Х18Н9Т, вместимостью $0,32 \mathrm{M}^{3}$, скоммуницирован с ЛУ, снабжен выносным мерным стеклом, измерителем температуры, змеевиковым охлаждением и пропеллерной мешалкой.

2. Мерник катализатора (М-11) аппарат из стали 1Х18Н9Т, вместимо-

Таблица 3

Загружено на стадии ТП-1.1

\begin{tabular}{|c|c|c|c|c|}
\hline \multicolumn{5}{|c|}{ Загружено } \\
\hline & Сырье и полупродукты & $\begin{array}{c}\text { Содержание } \\
\text { (\% масс) }\end{array}$ & $\begin{array}{c}\text { Macca техн., } \\
\kappa \Gamma / ч\end{array}$ & Macca $100 \%$, кг/ч \\
\hline \multirow{3}{*}{1 . } & Фенол технический, в т. ч. & & 298,22 & \\
\hline & фенол & 96,00 & & 286,29 \\
\hline & примеси & 4,00 & & 11,93 \\
\hline \multirow{3}{*}{2.} & Формалин 50 \%, в т. ч. & & 166,74 & \\
\hline & формальдегид & 50,00 & & 83,37 \\
\hline & вода & 50,00 & & 83,37 \\
\hline \multirow{4}{*}{3.} & Фенольная вода, в т. ч. & & 116,40 & \\
\hline & фенол & 30,00 & & 34,92 \\
\hline & формальдегид & 3,85 & & 4,48 \\
\hline & вода & 66,15 & & 77,00 \\
\hline & Итого: & & 581,36 & 581,36 \\
\hline
\end{tabular}

Получено на стадии ТП-1.1

Таблица 4

Получено

\begin{tabular}{|c|c|c|c|c|}
\hline & Сырье и полупродукты & $\begin{array}{c}\text { Содержание } \\
\text { (\% масс) }\end{array}$ & $\begin{array}{c}\text { Масcа техн., } \\
\kappa \Gamma / ч \\
\end{array}$ & Macca $100 \%$, кг/ч \\
\hline \multirow{5}{*}{1.} & Исходная смесь, в т. ч. & & 581,36 & \\
\hline & фенол & 55,25 & & 321,20 \\
\hline & примеси & 2,05 & & 11,93 \\
\hline & формальдегид & 15,11 & & 87,85 \\
\hline & вода & 27,59 & & 160,37 \\
\hline & Итого: & & 581,36 & 581,36 \\
\hline
\end{tabular}


Загружено на стадии ТП-1.2

Загружено

\begin{tabular}{c|l|c|c|c}
\hline \multicolumn{2}{c|}{ Сырье и полупродукты } & $\begin{array}{c}\text { Содержание } \\
\text { (\% масс) }\end{array}$ & $\begin{array}{c}\text { Масса техн., } \\
\text { кг/ч }\end{array}$ & $\begin{array}{c}\text { Масса } \mathbf{1 0 0} \%, \\
\text { кг/ч }\end{array}$ \\
\hline \multirow{2}{*}{1.} & $\begin{array}{l}\text { Кислота щавелевая } \\
\text { техническая, в т. ч. }\end{array}$ & 3,09 & \\
\cline { 2 - 5 } & щавелевая кислота & 95,50 & & 3,07 \\
\cline { 2 - 5 } & примеси & 0,50 & & 0,02 \\
\hline \multirow{2}{*}{ 2. Итого: } & Вода & & $\mathbf{1 0 , 3 0}$ & $\mathbf{1 0 , 2 1}$ \\
\hline \multicolumn{2}{|c|}{} & & & $\mathbf{1 0 , 3 0}$
\end{tabular}

Получено на стадии ТП-1.2

Таблица 6

Получено

\begin{tabular}{|c|c|c|c|c|}
\hline \multicolumn{2}{|r|}{ Сырье и полупродукты } & $\begin{array}{c}\text { Содержание } \\
\text { (\% масс) }\end{array}$ & $\begin{array}{c}\text { Масcа техн., } \\
\kappa г / ч\end{array}$ & Macca $100 \%$, кг/ч \\
\hline \multirow{4}{*}{1.} & Катализатор, в т. ч. & & 10,30 & \\
\hline & щавелевая кислота & 29,91 & & 3,07 \\
\hline & примеси & 0,10 & & 0,02 \\
\hline & вода & 69,99 & & 7,21 \\
\hline & Итого: & & 10,30 & 10,30 \\
\hline
\end{tabular}

стью 1 л, скоммуницирован с ЛУ, снабжен выносным мерным стеклом.

Одновременно с приготовлением исходной смеси из реактора $\mathrm{P}-10$, загружаемого 1 раз в сутки щавелевой кислотой и водой, сливается в мерник M-11 катализатор (водная суспензия щавелевой кислоты), который затем самотеком сливается на следующую стадию. Добавление кислоты регулируется по температуре и уровню смеси в основном реакторе (табл. 5-6).

\section{ТП-2. Поликонденсация}

Аппаратурное оформление стадии:

1. Реактор поликонденсации (Р-5) аппарат из стали 1Х18Н9Т, вместимостью $2 \mathrm{M}^{3}$, скоммуницирован с ЛУ, снабжен трубой передавливания, уровнемером, измерителями температуры и давления, гладкой рубашкой и якорной мешалкой.

2. Обратный холодильник (Хк-8) кожухотрубный аппарат из стали
1Х18Н9T, с сечением трубного пространства $0,013 \mathrm{M}^{2}$.

Поступающие с предыдущей стадии в заданном количестве через верхние штуцеры в основной реактор Р-5 исходная смесь и катализатор перемешиваются, в результате чего начинается химическая реакция фенола и формальдегида. Реакция идет при охлаждении стенок реактора водой при поддержании температуры - 98-100 ${ }^{\circ} \mathrm{C}$ в течение всего времени пребывания массы в аппарате (2 ч), откуда она сливается непрерывно через нижний штуцер. Испаряющиеся в ходе реакции летучие исходные вещества конденсируюся в обратном холодильнике Хк-8 и возвращаются в реакционную массу. Из реактора на выходе периодически берутся пробы продукта. Если продукт становится чрезмерно вязким, уменьшают скорость подачи катализатора. 
Загружено на стадии ТП-2

\begin{tabular}{|c|c|c|c|c|}
\hline & Сырье и полупродукты & $\begin{array}{c}\text { Содержание } \\
\text { (\% масс) }\end{array}$ & $\begin{array}{c}\text { Масса техн., } \\
\kappa \Gamma / ч\end{array}$ & $\begin{array}{c}\text { Macca } 100 \% \text {, } \\
\kappa \Gamma / ч\end{array}$ \\
\hline \multirow{5}{*}{1.} & Исходная смесь, в т. ч. & & 581,36 & \\
\hline & фенол & 55,25 & & 321,20 \\
\hline & примеси & 2,05 & & 11,93 \\
\hline & формальдегид & 15,11 & & 87,85 \\
\hline & вода & 27,59 & & 160,37 \\
\hline \multirow{4}{*}{2.} & Катализатор, в т. ч. & & 10,30 & \\
\hline & щавелевая кислота & 29,91 & & 3,07 \\
\hline & примеси & 0,10 & & 0,02 \\
\hline & вода & 69,99 & & 7,21 \\
\hline & Итого: & & 591,66 & 591,66 \\
\hline
\end{tabular}

Получено на стадии ТП-2

Таблица 8 Получено

\begin{tabular}{c|l|c|c|c}
\hline \multicolumn{2}{c|}{ Сырье и полупродукты } & $\begin{array}{c}\text { Содержание } \\
(\% \text { масс) }\end{array}$ & $\begin{array}{c}\text { Масса техн., } \\
\text { кг/ч }\end{array}$ & Масса 100 \%, кг/ч \\
\hline \multirow{2}{*}{1.} & Реакционная масса, в т.ч. & & 591,66 & \\
\cline { 2 - 5 } & ФФО & 49,99 & & 295,77 \\
\cline { 2 - 5 } & фенол & 9,23 & & 54,60 \\
\cline { 2 - 5 } & примеси & 2,02 & & 11,93 \\
\cline { 2 - 5 } & вода & 35,72 & & 211,33 \\
\cline { 2 - 5 } & щавелевая кислота & 0,52 & & 3,07 \\
\hline \multicolumn{2}{|c|}{ Итого: } & 2,52 & & $\mathbf{5 9 1 , 6 6}$
\end{tabular}

В реакторе предусмотрена труба передавливания для аварийной эвакуации смеси из реактора. При пуске установки начальное количество исходной смеси прогревается глухим паром (6 атм) до температуры реакции, и только затем в рубашку подается вода (табл. 7-8).

\section{ТП-3. Отделение водной фазы}

Аппаратурное оформление стадии:

1. Флорентийский сосуд (О-6) аппарат из стали 1Х18Н9T, вмести-

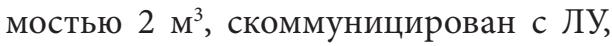
снабжен смотровым стеклом и гладкой рубашкой.

Из реактора Р-5 полученная смесь продукта с исходными веществами и образовавшейся в ходе реакции воды поступает на непрерывное отстаивание в обогреваемый паром (6 атм) флорентийский сосуд О-6. В сосуде происходит расслаивание смеси на водную и органическую фазы; первая сливается через верхний штуцер и поступает в цех утилизации либо в цех производства резольных смол, вторая - передавливается насосом на стадию сушки через нижний штуцер (табл. 9-10).

\section{ТП-4. Сушка и декарбоксилирова-} ние

Аппаратурное оформление стадии:

Сушилка (С-7) - кожухотрубный аппарат из стали 1Х18Н9T, с сечением трубного пространства 0,259 м², оборудован вакууметром на выходе из трубного пространства. 
Загружено на стадии ТП-3

Загружено

\begin{tabular}{|c|c|c|c|c|}
\hline \multicolumn{2}{|c|}{ Сырье и полупродукты } & $\begin{array}{c}\text { Содержание } \\
\text { (\% масс) }\end{array}$ & $\begin{array}{c}\text { Macca техн., } \\
\kappa г / ч\end{array}$ & Macca $100 \%$, кг/ч \\
\hline \multirow{7}{*}{1.} & Реакционная масса, в т. ч. & & 591,66 & \\
\hline & ФФО & 49,99 & & 295,77 \\
\hline & фенол & 9,23 & & 54,60 \\
\hline & примеси & 2,02 & & 11,93 \\
\hline & вода & 35,72 & & 211,33 \\
\hline & щавелевая кислота & 0,52 & & 3,07 \\
\hline & формальдегид & 2,52 & & 14,93 \\
\hline & Итого: & & 591,66 & 591,66 \\
\hline
\end{tabular}

Таблица 10

Получено на стадии ТП-3

Получено

\begin{tabular}{|c|c|c|c|c|}
\hline & Сырье и полупродукты & $\begin{array}{c}\text { Содержание } \\
\text { (\% масс) }\end{array}$ & $\begin{array}{c}\text { Мacca техн., } \\
\kappa \Gamma / ч\end{array}$ & $\begin{array}{c}\text { Macca } 100 \%, \\
\kappa г / ч\end{array}$ \\
\hline \multirow{6}{*}{1.} & Отстойная смола, в т. ч. & & 417,10 & \\
\hline & ФФО & 70,84 & & 295,48 \\
\hline & фенол & 11,39 & & 47,51 \\
\hline & щавелевая кислота & 0,74 & & 3,07 \\
\hline & формальдегид & 1,07 & & 4,48 \\
\hline & вода & 15,96 & & 66,57 \\
\hline \multirow{6}{*}{2.} & Надсмольная вода, в т. ч. & & 174,56 & \\
\hline & вода & 75,27 & & 144,76 \\
\hline & фенол & 5,62 & & 7,10 \\
\hline & формальдегид & 8,28 & & 10,45 \\
\hline & примеси & 10,61 & & 110,93 \\
\hline & ФФО & 0,23 & & 0,30 \\
\hline & Итого: & & 591,66 & 591,66 \\
\hline
\end{tabular}

Со стадии разделения отстойная смола закачивается в сушилку С-7, выполненную в виде кожухотрубчатого теплообменника, обогреваемого паром высокого давления (12 атм) для создания температуры $140-180{ }^{\circ} \mathrm{C}$. Смола подается в трубчатое пространство, внутри которого создается средний вакуум, и движется в виде пленки за счет потока отгоняемых из нее летучих веществ, а также газообразных продуктов разлагающейся в ходе процесса щавелевой кислоты. Высушенная смола далее подается на сле- дующую стадию, а парогазовая фаза уходит на конденсацию и образование фенольной воды в сборник Сб-12 (табл. 11-12).

Ввиду необходимости нагрева паром высокого давления на стенках труб остается заполимеризовавшаяся смола, которую приходится периодически удалять.

\section{ТП-5. Термообработка}

Аппаратурное оформление стадии: Смолоприемник (Сб-8) - аппарат из стали $1 \mathrm{X} 18 \mathrm{H} 9 \mathrm{~T}$, вместимостью $2 \mathrm{M}^{3}$, скоммуницирован с ЛУ, снабжен тру- 
Загружено на стадии ТП-4

Загружено

\begin{tabular}{|c|c|c|c|c|}
\hline \multicolumn{2}{|r|}{ Сырье и полупродукты } & $\begin{array}{c}\text { Содержание } \\
\text { (\% масс) }\end{array}$ & $\begin{array}{c}\text { Масcа техн., } \\
\kappa г / ч\end{array}$ & $\begin{array}{c}\text { Macca } 100 \% \text {, } \\
\kappa г / ч\end{array}$ \\
\hline \multirow{6}{*}{1 . } & Отстойная смола, в т. ч. & & 417,10 & \\
\hline & $\Phi \Phi О$ & 70,84 & & 295,48 \\
\hline & фенол & 11,39 & & 47,51 \\
\hline & щавелевая кислота & 0,74 & & 3,07 \\
\hline & формальдегид & 1,07 & & 4,48 \\
\hline & вода & 15,96 & & 66,57 \\
\hline & Итого: & & 417,10 & 417,10 \\
\hline
\end{tabular}

Получено на стадии ТП-4

Таблица 12

Получено

\begin{tabular}{|c|c|c|c|c|}
\hline \multicolumn{2}{|r|}{ Сырье и полупродукты } & $\begin{array}{c}\text { Содержание } \\
\text { (\% масс) }\end{array}$ & $\begin{array}{c}\text { Масcа техн., } \\
\kappa \Gamma / ч\end{array}$ & $\begin{array}{c}\text { Macca } 100 \% \text {, } \\
\kappa г / ч\end{array}$ \\
\hline \multirow{3}{*}{1.} & Высушенная смола, в т. ч. & & 306,59 & \\
\hline & $\Phi \Phi О$ & 95,89 & & 294,00 \\
\hline & фенол & 4,11 & & 12,59 \\
\hline 2. & Потери & & 1,48 & 1,48 \\
\hline \multirow{6}{*}{3.} & Парогазовая фаза, в т. ч. & & 109,04 & \\
\hline & вода & 61,05 & & 67,18 \\
\hline & формальдегид & 4,11 & & 4,48 \\
\hline & углекислый газ & 1,38 & & 1,50 \\
\hline & угарный газ & 0,88 & & 0,96 \\
\hline & фенол & 32,58 & & 34,92 \\
\hline & Итого: & & 417,10 & 417,10 \\
\hline
\end{tabular}

Загружено на стадии ТП-5

Таблица 13

Загружено

\begin{tabular}{|c|c|c|c|c|}
\hline \multicolumn{2}{|r|}{ Сырье и полупродукты } & $\begin{array}{c}\text { Содержание } \\
\text { (\% масс) }\end{array}$ & $\begin{array}{c}\text { Macca техн., } \\
\kappa г / ч \\
\end{array}$ & $\begin{array}{c}\text { Macca } 100 \% \text {, } \\
\text { Кг } / ч\end{array}$ \\
\hline \multirow{3}{*}{1.} & Высушенная смола, в т. ч. & & 306,59 & \\
\hline & $\Phi Ф О$ & 95,89 & & 294,00 \\
\hline & фенол & 4,11 & & 12,59 \\
\hline 2. & Острый пар & & 359,89 & 359,89 \\
\hline & Итого: & & 666,47 & 666,47 \\
\hline
\end{tabular}

бой передавливания, уровнемером, измерителями температуры и давления, змеевиковой полутрубной рубашкой и якорной мешалкой.

Высушенная смола в расплаве заливается в смолоприемник Сб-8, представляющий из себя емкостной аппарат с рубашкой и мешалкой. Смола подается до заданного уровня наполнения, после чего входящий поток переводится на второй смолоприемник, а в аппарат через трубу передав- 
Получено на стадии ТП-5

Получено

\begin{tabular}{c|l|c|c|c}
\hline \multicolumn{2}{c|}{ Сырье и полупродукты } & $\begin{array}{c}\text { Содержание } \\
\text { (\% масс) }\end{array}$ & $\begin{array}{c}\text { Масса техн., } \\
\text { кг/ч }\end{array}$ & $\begin{array}{c}\text { Масса } 100 \%, \\
\text { кг/ч }\end{array}$ \\
\hline \multirow{2}{*}{1.} & Товарная смола, в т. ч. & & 299,99 & \\
\cline { 2 - 5 } & ФО & 98,00 & & 294,00 \\
\cline { 2 - 5 } & фенол & 2,00 & & 5,99 \\
\hline \multirow{2}{*}{2.} & Отгон фенола, в т. ч. & & 366,48 & 6,60 \\
\cline { 2 - 5 } & фенол & 1,80 & & \\
\cline { 2 - 5 } & вода Итого: & & 666,47 & \\
\hline
\end{tabular}

Таблица 15

Основные технологические параметры и контроль производства

\begin{tabular}{|c|c|c|c|c|}
\hline $\begin{array}{c}\text { Контрольная } \\
\text { точка }\end{array}$ & $\begin{array}{c}\text { Наименование } \\
\text { объекта контроля }\end{array}$ & $\begin{array}{c}\text { Контролируемый } \\
\text { параметр } \\
\text { и размерность }\end{array}$ & Норматив & $\begin{array}{c}\text { Метод } \\
\text { и средство } \\
\text { контроля } \\
\end{array}$ \\
\hline $\begin{array}{l}\text { Реактор Р-5, } \\
\text { КT-1 }\end{array}$ & $\begin{array}{l}\text { Реакционная } \\
\text { масса }\end{array}$ & Температура, ${ }^{\circ} \mathrm{C}$ & $\begin{array}{l}\text { Не более } \\
100^{\circ} \mathrm{C} \\
\text { Не менее } \\
97^{\circ} \mathrm{C} \\
\end{array}$ & $\begin{array}{l}\text { Датчик с } \\
\text { выводом на } \\
\text { щите }\end{array}$ \\
\hline $\begin{array}{l}\text { Реактор Р-5, } \\
\text { КТ-2 }\end{array}$ & $\begin{array}{l}\text { Реакционная } \\
\text { масса }\end{array}$ & Вязкость, МПа · с & Не более 1200 & Лабораторно \\
\hline $\begin{array}{l}\text { Сушилка С-7, } \\
\text { КТ-3 }\end{array}$ & Режим работы & Вакуум, атм & 0,3 & $\begin{array}{l}\text { Вакуумметр } \\
\text { на выходе }\end{array}$ \\
\hline $\begin{array}{l}\text { Смолоприем- } \\
\text { ник, КТ-4 }\end{array}$ & $\begin{array}{l}\text { Реакционная } \\
\text { масса }\end{array}$ & $\begin{array}{l}\text { Температура ка- } \\
\text { плепадения, }{ }^{\circ} \mathrm{C}\end{array}$ & $\begin{array}{l}\text { В зависимо- } \\
\text { сти от марки } \\
\text { олигомера } \\
\end{array}$ & $\begin{array}{l}\text { Лабораторно } \\
\text { по методу } \\
\text { Уббелоде } \\
\end{array}$ \\
\hline $\begin{array}{l}\text { Смолоприем- } \\
\text { ник. КТ-4 }\end{array}$ & Масса на выходе & $\begin{array}{l}\text { Содержание фено- } \\
\text { ла, \% }\end{array}$ & Не более 2 & Лабораторно \\
\hline
\end{tabular}

ливания подается острый пар (6 атм). При нагреве острым и глухим паром (12 атм) температура поддерживается в диапазоне $130-190{ }^{\circ} \mathrm{C}$, в результате чего с паром отгоняется избыточный фенол, идущий затем на конденсацию и утилизацию. Из аппарата периоди- чески отбираются пробы на проверку соответствия стандартизованным параметрам. После окончания процесса готовая товарная смола поступает на грануляцию и затаривание (табл. 13-14). 


\section{Заключение}

В данной работе представлена модификация технологической схемы производства новолачных фенолформальдегидных олигомеров. Составлен аналитический обзор, в котором приведена краткая характеристика сырья, исходных веществ и влияние каждого типа фенольного и формальдегидного сырья на технологические и физикомеханические свойства продукта.

В технологической части дана характеристика готовой продукции, исходного сырья и материалов, приведено подробное описание технологии и технологической схемы производства (табл. 15).

\section{Bibliography}

1. Brazihin E. A., Shulgina E. S. Technology of plastics: textbook for technical schools. 3rd ed. Rev. and extra. L.: Chemistry, 1982. 328 p.

2. Bachmann A., Muller K. Phenolic Plastics. Transl. from Germ. M.: Chemistry, 1978. 288- Leipzig, 1973.

3. Vorobev V. A., Andrianov, R. A. Technology of polymers: Textbook for universities. 2nd ed. M.: Higher. school, 1980. 303 p.

Cite this article as (как цитировать эту статью):

Galushchinsky A. N., Obydennov K. L. The production of novolac oligomers. Chimica Techno Acta. 2016;3(4):242-267. 